\title{
MECHANICAL, THERMAL, MORPHOLOGICAL PROPERTIES AND DECAY RESISTANCE OF FILLED HAZELNUT HUSK POLYMER COMPOSITES
}

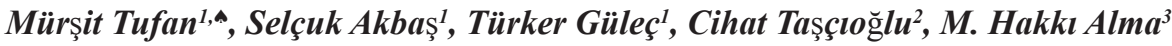

\begin{abstract}
Four different formulations of natural fiber-polymer composites were fabricated from mixtures of hazelnut (Corylus avellana) husk flour (HHF), polypropylene (PP) and high density polyethylene (HDPE). Variables examined included polymer and coupling agent types. All formulations were compression molded in a hot press for 3 minutes at $175{ }^{\circ} \mathrm{C}$. The resulted specimens were tested for mechanical properties according to ASTM D-790 and ASTM D-638. In addition, scanning electron microscopy (SEM), thermogravimetry (TG) and Differential Scanning Calorimetry (DSC) analysis were performed to characterize rheological properties of the fabricated composite. Furthermore, decay tests were performed to determine degradation of hazelnut husk polymer matrices. Hazelnut husk polymer composites had high mechanical properties for the tested formulations. The thermal studies showed that incorporation of hazelnut husk into the polymer matrices used did not adversely affect the composite. The HDPE $+50 \%$ wood $+3 \%$ MAPE (HHF2) formulation showed the highest natural durability with only $3,47 \%$ and 4,60\% mass losses against Trametes versicolor and Postia plecenta, respectively, while Scots pine solid controls experienced around $32 \%$ mass loss under the same exposure condition.
\end{abstract}

Keywords: Corylus avellana, decay resistance, mechanical properties, Pinus sylvestris, polymer composites, Postia plecenta, Trametes versicolor.

\section{INTRODUCTION}

The demand for natural and synthetic products has increased in parallel with the increasing world population. Depending on the production processes of these products, substantial amount of waste material has been generated, thus resulting in environmental pollution. As a result, utilization of renewable resources gained importance (Wang and Zhu 2010). Lignocellulose is the most abundant and widely utilized renewable material on earth (Mengeloglu and Karakus 2008). However, utilization of annual plants became more practical in some countries, such as Turkey, which has very limited forest resources. This provides a great deal of benefit to the economy of the country (Ashori 2009, Wang et al. 2009).

Polymer-composites can be made from wood and annual plant fiber or flours mixed with polymers such as high density polyethylene (HDPE), polypropylene (PP) and polyvinyl chloride (PVC). The resulting material have many applications because of their properties such as enhanced strength, stiffness, creep, physical and mechanical properties and dimensional stability (Clemons 2002, Mengeloglu et al. 2000, Mengeloglu and Matuana 2003, Youngquist 1995). The market share of these products have grown dramatically in Northern America and Europe by $18 \%$ and 14\% during the last decade, respectively (Wang and Wong 2007, Ashori 2008). Addition of lignocellulosic material offers many benefits to the final product such as lower weight, decreased erosion of the manufacturing machinery, lower cost and the absence of production of residue or toxic by-products when burnt. Thus lignocellulosic materials are preferred as a filler in producing the polymer-composites (Ismail et al. 2001, Matuana et al. 1998).

\footnotetext{
Department of Forest Products Engineering, Faculty of Forestry, Artvin Coruh University, Artvin. Turkey.

2 Department of Forest Products Engineering, Faculty of Forestry, Duzce University, Duzce. Turkey.

Department of Forest Products Engineering, Faculty of Forestry, Kahramanmaras Sutcu Imam University, Kahramanmaraş. Turkey.

^ Corresponding author: mtufan35@hotmail.com

Received: 06.08.2014 Accepted: 27.07.2015
} 
Hazelnut (Corylus avellana) plantations cover 690000 hectares of land in Turkey. Nearly $70 \%$ of the world hazelnut production is in Turkey and 660000 tons of nuts are produced annually. Accordingly, every year about 260 thousand tons of hazelnut husk (outer leaves of hazelnut) waste is produced. This waste is used for heating purposes in household (Kooperatg்fç̇glġk Genel Müdürlüğü 2013), but there is limited information on hazelnut utilization. This study, investigated the utilization of this material as a reinforcement material for composite manufacturing.

\section{MATERIALS and METHODS}

\section{Materials}

High density polyethylene (HDPE), Polypropylene (PP), hazelnut husk flour (HHF), maleic anhydrite grafted polyethylene (MAPE) and polypropylene (MAPP) coupling agent were used as thermoplastic matrix, organic filler and coupling agent, respectively. PE (SO 464) and PP (MH 418) homopolymer were provided by Petrokimya Holding A.Ş. (PETKIM) and MAPE (PE MA 4351 GR) and MAPP (PP MA 6452 TP) were provided by Clariant International Ltd. HH waste was supplied from Espiye, Giresun. The experimental design of the study is presented in Table 1.

Table 1. Composition of the Polymer Composites evaluated in this study.

\begin{tabular}{|c|c|c|c|c|c|}
\hline \multirow{3}{*}{ Group ID } & \multicolumn{5}{|c|}{ Composite Composition (mass/mass) } \\
\hline & \multirow{2}{*}{$\begin{array}{l}\text { HS flour } \\
(\%)\end{array}$} & \multicolumn{2}{|c|}{$\begin{array}{c}\text { Polymer Type } \\
(\%)\end{array}$} & \multicolumn{2}{|c|}{$\begin{array}{c}\text { Coupling Agent Type } \\
(\%)\end{array}$} \\
\hline & & HDPE & PP & MAPE & MAPP \\
\hline HDPE & - & 100 & - & - & - \\
\hline HHF1 & 50 & 50 & - & - & - \\
\hline HHF2 & 50 & 47 & - & 3 & - \\
\hline PP & - & - & 100 & - & - \\
\hline HHF3 & 50 & - & 50 & - & - \\
\hline HHF4 & 50 & - & 47 & - & 3 \\
\hline
\end{tabular}




\section{METHODS}

\section{Preparation of compression molded polymer composites}

The air dried $\mathrm{HH}$ was ground in a Willey mill pass to 60 and 80 mesh particle sizes and dried at $100^{\circ} \mathrm{C}$. The HHF, polymers and coupling agent granulates were processed in a co-rotating single-screw extruder (RONDOL 3212). The four barrel temperature zones of the extruder were controlled at 175 and $190{ }^{\circ} \mathrm{C}$. The extruded strand passed through a water bath and was subsequently pelletized. Finally, pellets were compression molded in a the hot press for 3 minutes at $175^{\circ} \mathrm{C}$ and $10 \mathrm{MPa}$. The WPCs were produced in dimensions of $150 \mathrm{~mm}$ in [length $(\mathrm{L})] \times 170 \mathrm{~mm}$ in [width $(\mathrm{W})] \times 5 \mathrm{~mm}$ in [thickness $(\mathrm{T})$ ].

\section{Determination of Mechanical Properties}

The properties of the manufactured composites were conducted in a climate-controlled testing laboratory at $23 \mathrm{C}^{\circ}$ and $65 \% \mathrm{RH}$. Flexural, tensile and impact properties were determined. The flexural properties of the specimens with dimensions of $150(\mathrm{~L}) \times 13(\mathrm{~W}) \times 5(\mathrm{~T}) \mathrm{mm}$, modulus of rupture (MOR) and modulus of elasticity (MOE), were measured in three-point bending test in accordance with ASTM D 790. The tensile tests were performed according to ASTM D 638. The specimens were tested with a crosshead speed of $5 \mathrm{~mm} / \mathrm{min}$. Dog-bone shape samples were used (type III) and all tests were performed on Zwick 10KN Universal Testing Machine (Zwick Inc. Germany).Seven samples for each group were tested.

\section{Scanning Electron Microscopy}

One sample of each material was dipped in liquid nitrogen and then fractured. The fractured surfaces of tensile test specimens were studied using a JEAL scanning electron microscope (SEM) (JEAL/ NEOSCOPE JCM-5000) under an acceleration voltage of $10 \mathrm{kV}$. Two samples from each group were selected. Different areas of selected examples were scanned. The samples were sputter coated with gold to provide electrical conductivity.

\section{Thermogravimetry and Differential Scanning Calorimetry}

The extrusion pellets were grinded with a Willey mill prior to analysis. Thermo-gravimetric analysis of the samples was done by using the PerkinElmer STA 6000 thermal analyzer. For the TGA test, samples (3-5 mg) were heated in an aluminum pan up to $600{ }^{\circ} \mathrm{C}$ with the heating rate of $10{ }^{\circ} \mathrm{C} / \mathrm{min}$ and kept at this temperature for $2 \mathrm{~min}$ to monitor thermal history. Additionally, the melting behavior of the samples was studied on a Differential Scanning Calorimeter (DSC) (PelkinElmer DSC 4000) in the temperature range between 25 to $250{ }^{\circ} \mathrm{C}$, at $10^{\circ} \mathrm{C} / \mathrm{min}$ heating rate under nitrogen with a $30 \mathrm{~mL} / \mathrm{min}$ flow rate.

\section{Decay Tests}

Polymer composites (HHF1, HHF2, HHF3 and HHF4) and Scots pine (Pinus sylvestris L.) solid wood specimens as controls samples were carried out according to European standard EN 113. Test specimens of $[20(\mathrm{~L}) \times 20(\mathrm{~W}) \times 5(\mathrm{~T})] \mathrm{mm}$ were dried at $101 \pm 3{ }^{\circ} \mathrm{C}$ for 48 hours and weighed to the nearest $0,01 \mathrm{~g}$ to determine the initial weight $\left(\mathrm{M}_{1}\right)$. One white rot fungus, Trametes versicolor L.Pilat (Mad-697) and one brown rot fungi, Postia placenta (Fr.) M.J. Larsen \& Lombard (Mad-698-R were used for the decay tests. All test fungi were grown on a 4.8\% malt extract agar. A mycelium plug of the appropriate test fungus was transferred to the center of each Petri dish. The dishes were incubated at 24 $\pm 2{ }^{\circ} \mathrm{C}$ and $75 \% \mathrm{RH}$ until the fungal mycelium reached the edges of the dishes. Six specimens of each formulation were sterilized in an autoclave for $30 \mathrm{~min}$ at $121{ }^{\circ} \mathrm{C}$ and placed in the pre-inoculated Petri dishes. Samples were placed on plastic screens in petri dishes so there is no direct contact between the agar and specimen surfaces. 
At the end of the exposure time ( 16 weeks), the surfaces of the specimens were cleaned and weighed immediately to determine post-decay weight of the samples. The specimens were then dried at $101 \pm$ $3{ }^{\circ} \mathrm{C}$ for 48 hours $\left(\mathrm{M}_{2}\right)$ for the calculation of the mass loss. The percent mass loss (ML) was calculated as follows,

$$
M L(\%)=\left[\left(\frac{M_{1}-M_{2}}{M_{1}}\right)\right] x 100
$$

A set of Scots pine (Pinus sylvestris) specimens were also tested as a control against both fungi used in this experiment.

\section{Statistical Analysis}

The mechanical and decay data were subjected to an analysis of variance (ANOVA). All means were compared using Duncan's multiple comparison test at $\alpha=0,05$ using a SPSS statistical program (SPSS 19. 2010).

\section{RESULTS}

\section{Mechanical Properties}

Flexural and tensile strength, flexural and tensile modulus, elongation at break values of HHF-HDPE composites are shown Table 2. Flexural and tensile strength, elongation at break values decreased with the addition of HHF in the composites. Flexural and tensile strength values increased by $52 \%$ and $54 \%$ respectively, when a coupling agent was added but elongation at break value did not change significantly.

Flexural and tensile modulus values increased $35 \%$ and $23 \%$ respectively, while strength properties decreased when HFF was added to composite.

Table 2. Mechanical properties of HHF filled HDPE and PP composites.

\begin{tabular}{|c|c|c|c|c|c|}
\hline Group ID & $\begin{array}{c}\text { Flexural } \\
\text { Strength (MPa) }\end{array}$ & $\begin{array}{c}\text { Flexural } \\
\text { Modulus (GPa) }\end{array}$ & $\begin{array}{c}\text { Tensile Strength } \\
\text { (MPa) }\end{array}$ & $\begin{array}{c}\text { Tensile Modulus } \\
\text { (GPa) }\end{array}$ & $\begin{array}{c}\text { Elongation at } \\
\text { Break (\%) }\end{array}$ \\
\hline HDPE & $\begin{array}{c}31,43 \mathrm{c} \\
(0,59)\end{array}$ & $\begin{array}{c}1,3 \mathrm{a} \\
(0,02)\end{array}$ & $\begin{array}{c}21,72 \mathrm{c} \\
(2,90)\end{array}$ & $\begin{array}{l}0,3,9 \mathrm{a} \\
(0,18)\end{array}$ & $\begin{array}{c}15,63 \mathrm{~b} \\
(0,45)\end{array}$ \\
\hline HHF1 & $\begin{array}{c}19,21 \text { a } \\
(0,42)\end{array}$ & $\begin{array}{l}1,7 \mathrm{~b} \\
(0,07)\end{array}$ & $\begin{array}{c}10,65 \mathrm{a} \\
(1,03)\end{array}$ & $\begin{array}{l}1,3 \mathrm{~b} \\
(0,19)\end{array}$ & $\begin{array}{l}2,87 \mathrm{a} \\
(0,38)\end{array}$ \\
\hline HHF2 & $\begin{array}{c}29,24 \mathrm{~b} \\
(1,01)\end{array}$ & $\begin{array}{l}2,3 \mathrm{c} \\
(0,2)\end{array}$ & $\begin{array}{c}16,46 \mathrm{~b} \\
(2,68)\end{array}$ & $\begin{array}{c}1,6 \mathrm{c} \\
(0,18) \\
\end{array}$ & $\begin{array}{l}2,42 \mathrm{a} \\
(0,25) \\
\end{array}$ \\
\hline PP & $\begin{array}{c}32,22 \mathrm{c} \\
(3,01)\end{array}$ & $\begin{array}{l}0,96 \mathrm{a} \\
(0,08) \\
\end{array}$ & $\begin{array}{c}23,87 \mathrm{c} \\
(1,44)\end{array}$ & $\begin{array}{l}0,38 \mathrm{a} \\
(0,02)\end{array}$ & $\begin{array}{c}14,10 \mathrm{~b} \\
(2,65)\end{array}$ \\
\hline HHF3 & $\begin{array}{c}20,48 \mathrm{a} \\
(3,94)\end{array}$ & $\begin{array}{l}2,3 \mathrm{~b} \\
(0,22)\end{array}$ & $\begin{array}{c}10,65 \mathrm{a} \\
(1,06)\end{array}$ & $\begin{array}{l}1,3 \mathrm{~b} \\
(0,21)\end{array}$ & $\begin{array}{l}1,71 \mathrm{a} \\
(0,20)\end{array}$ \\
\hline HHF4 & $\begin{array}{c}28,42 \mathrm{~b} \\
(2,43)\end{array}$ & $\begin{array}{l}2,5 \mathrm{~b} \\
(0,29)\end{array}$ & $\begin{array}{c}15,90 \mathrm{~b} \\
(2,81)\end{array}$ & $\begin{array}{l}1,4 \mathrm{~b} \\
(0,24)\end{array}$ & $\begin{array}{l}1,97 \mathrm{a} \\
(0,26)\end{array}$ \\
\hline
\end{tabular}

Note:

-The values in parenthesis are standard deviations.

-Each value is the average of seven samples tested.

-Groups with the same letters in a column indicate no difference statistically $(p<0,05)$.

Table 2 shows the mechanical properties of the HHF-PP composites. Strength and elongation break values decreased with addition of HHF in composites composed of both HHF-HDPE and PP (Table 2). The Coupling agent addition to the HHF-PP composites improved flexural and tensile strength values by $38 \%$ and $49 \%$, respectively. 
All HHF-PP composites had higher modules values than that of PP composite group. Flexural and tensile modulus values increased sharply with addition of HHF in to composites. Flexural modulus, tensile modulus and elongation at break values increased slightly with the addition of a coupling agent in HHF filled PP composites, but the differences not significant $(p<0,05)$. It is well known that the mechanical properties of composites depend on mainly interaction between lignocellulosic filler and the thermoplastic materials. Because plastics are hydrophobic substances that are not compatible with hydrophilic lignocellulosics, resulting poor adhesion between plastic and HHF in composites (Sanadi et al. 1994). One way to improve this to incorporate a coupling agent as an additive. The addition of coupling agent improved the strength properties of all groups in this study. Similar results reported by the others (Mengeloglu et al. 2007, Kord 2012, Basiji et al. 2010, Yang et al. 2007, Li and Matuana 2003, Gallagher and McDonald 2013).

Surface adhesion was improved by the addition of 3\% MAPE in treatments HHF2 and HHF4 (Figures 1 and 2). Wood particles were well dispersed in the polymer matrix (Figures 1 and 2). Indicating, good encapsulation of the lignocellulosic matrix. However some pulled-out fibers could still be observed in the polymer composites.

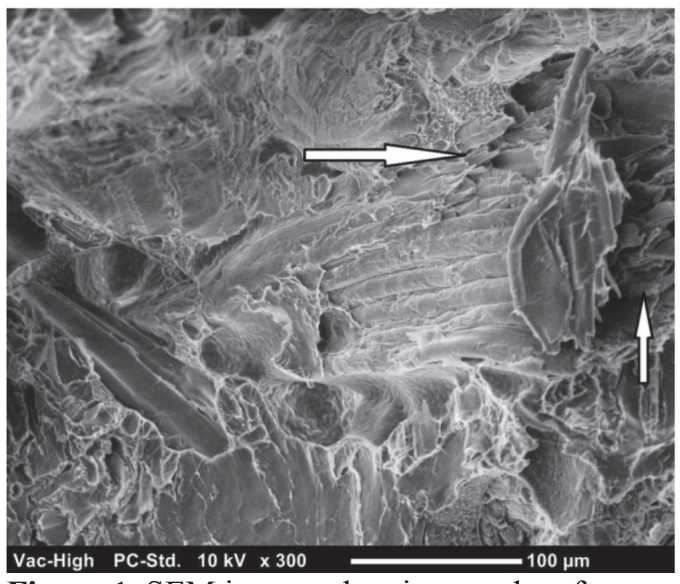

Figure 1. SEM images showing good surface adhesion HDPE composites (magnification $\mathrm{x}$ 300 and scale bar $100 \mu \mathrm{m})$.

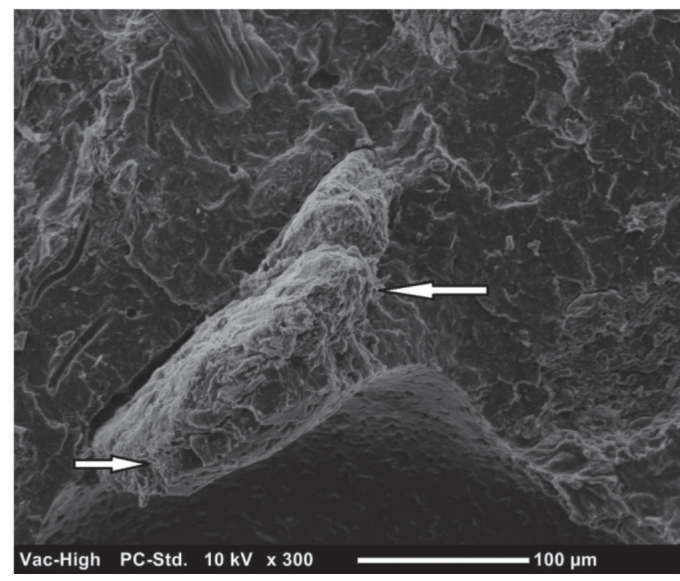

Figure 2. SEM images showing good surface adhesion PP composites (magnification x 300 and scale bar $100 \mu \mathrm{m})$.

\section{Thermogravemetric analysis (TGA) and Differential Scanning Calorimetry (DSC)}

The results of TGA analysis are shown in Figure 3. Degradation of all polymer composites first decomposition temperature peak started at around $220{ }^{\circ} \mathrm{C}$, which is similar to the degradation temperature of lignocellulosic materials, hemicellulose, cellulose and lignin. Degradation temperatures are approximately $180{ }^{\circ} \mathrm{C}, 210{ }^{\circ} \mathrm{C}$ and $200{ }^{\circ} \mathrm{C}$, respectively (Xu et al. 2006, Canetti et al. 2006, Sain and Panthapulakkal 2006). Second decomposition temperature peak gives the highest decomposition temperature at $480^{\circ} \mathrm{C}$. It is known that HDPE degrades at around this temperature (Tascioglu et al. 2014). 


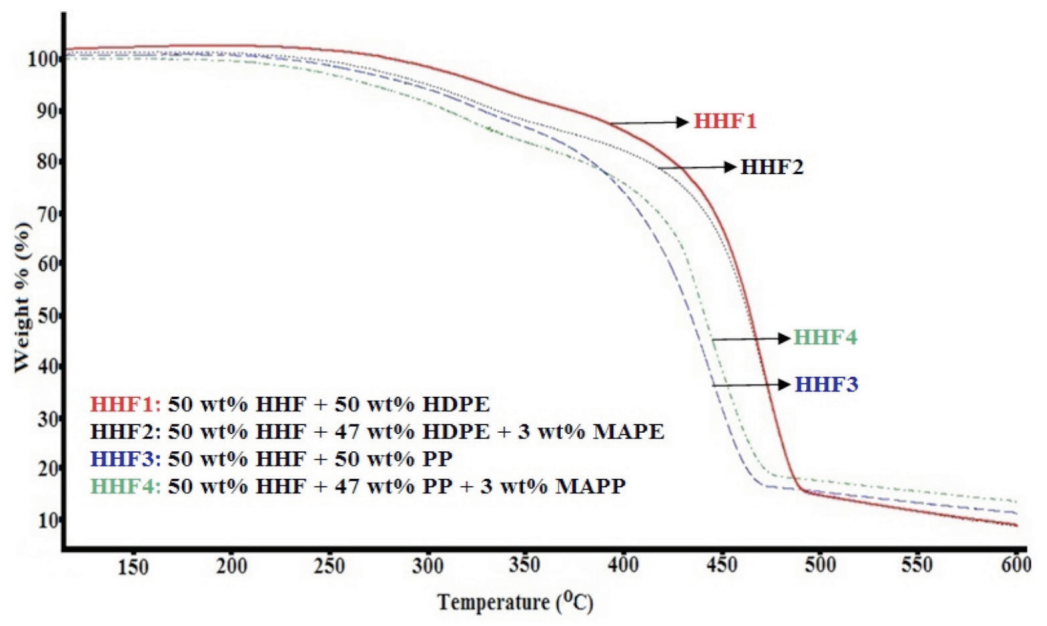

Figure 3. TGA results of HHF filled HDPE and PP polymer composites.

The DSC results of HHF filled HDPE and PP polymer composites are presented in Figure 4. Melting temperature were around HHF1 and HHF2 $130{ }^{\circ} \mathrm{C}$ while HHF3 and HHF4 $170{ }^{\circ} \mathrm{C}$. Also we know that melting point of virgin $\mathrm{HDPE}$ and $\mathrm{PP}$ are around $130^{\circ} \mathrm{C}$ and $175^{\circ} \mathrm{C}$ respectively (Klyosov 2007, Moreno et al. 2013).

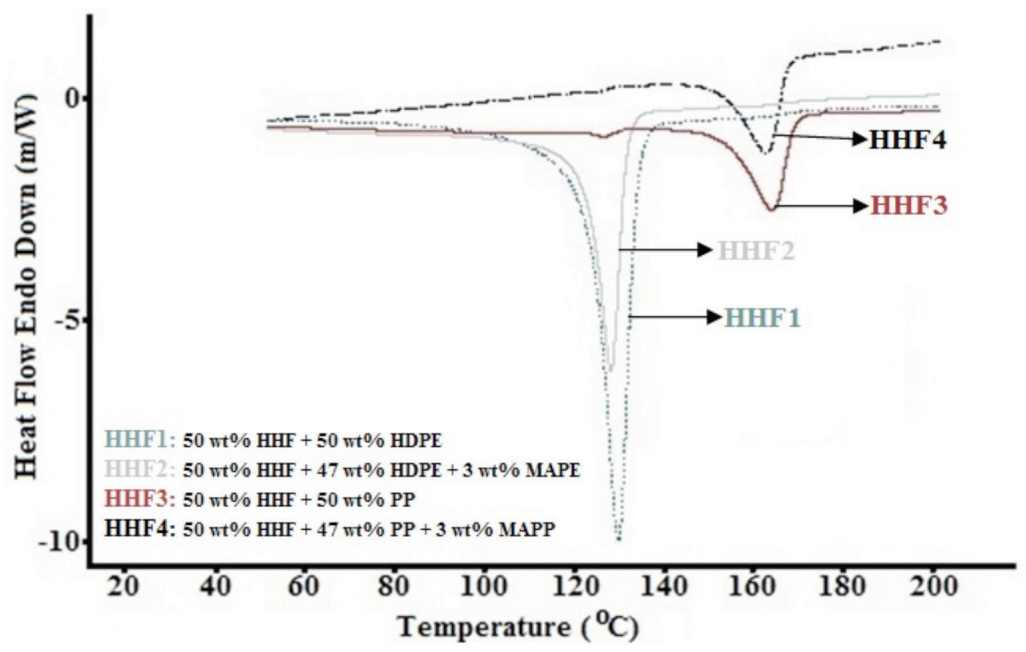

Figure 4. DSC results of HHF filled HDPE and PP polymer composites. 
Decay Test

Table 3 summarizes the results of decay test of polymer composites and solid wood control specimens.

Table 3. Mean mass loss (\%) of polymer composites after a 16-week exposure to decay fungi.

\begin{tabular}{|c|c|c|c|c|}
\hline Group ID & T. versicolor & $\begin{array}{c}\text { Post-decay } \\
\text { MC (\%) }\end{array}$ & P. Placenta & $\begin{array}{c}\text { Post-decay MC } \\
(\%)\end{array}$ \\
\hline HHF1 & $7,59(1,36)$ a & $10,88(1,57)$ & $7,33(0,69)$ a & $8,81(1,60)$ \\
\hline HHF2 & $3,47(0,33)$ a & $5,51(0,83)$ & $4,60(0,87)$ a & $4,57(0,53)$ \\
\hline HHF3 & $6,96(1,22)$ a & $8,01(1,43)$ & $5,72(0,12)$ a & $3,26(0,63)$ \\
\hline HHF4 & $7,62(0,65)$ a & $7,73(1,66)$ & $5,59(0,67)$ a & $3,30(0,52)$ \\
\hline Scots pine control & $32,55(9,42)$ b & $41,32(5,21)$ & $31,99(7,29) \mathrm{b}$ & $36,84(6,11)$ \\
\hline
\end{tabular}

Note:

-The value in parenthesis is the standard deviation.

-Each value is the average of six samples tested.

-Groups with same letters in column indicate that there is no statistical difference $(\mathrm{p}<0,05)$

Mass losses produced by the white and brown rot fungi were 31,99\% and 32,55\%; for control wood blocks, respectively, indicating that conditions were favorable for aggressive fungal attack. None of the weight losses exceeded $8 \%$ for the white and brown rot fungi exposed to polymer composites. The smallest mass loss has been found for white rot and brown rot 3,47\% - 4,60\% respectively (HHF2) with added $3 \%$ coupling agent. Results indicate that mass loss rate was decreased approximately at $45 \%$ by using coupling agent for HDPE while that statistically not significant for all polymer composites.

Previously literature suggests mass loss range between 3\% and $6 \%$ for the same formulation $(50 / 50)$ WPCs tested against white rot in accordance with related standards (Tascioglu et al. 2013, Verhey et al. 2001, Schirp and Wolcott 2005). Kartal et al. 2011, has found same results for decay rate for brown rot fungus (T. palustris ) (Kartal et al. 2013). Result shows that polymer composite has resistance to decay despite good fungal colonization on the composite surfaces. Similar results were reported by other authors (H'ng et al. 2011, Khavkine et al. 2001). 


\section{CONCLUSIONS}

The following conclusions were obtained from this research:

All of the polymer composites had good mechanical properties that met the minimum flexural strength of $6,9 \mathrm{MPa}$ and flexural modulus of $0,34 \mathrm{Gpa}$. The results indicate that HHF can be successfully used as an alternative filler material in wood-plastic composite production.

During the manufacturing of polymer composite melting point and the degradation temperature of the filler have great importance. Based on the TGA and DSC analysis during the manufacturing of polymer composite extruder temperature should be over $130{ }^{\circ} \mathrm{C}$ and $170{ }^{\circ} \mathrm{C}$ for HDPE and PP respectively and should be less than $220^{\circ} \mathrm{C}$ to prevent the HHF from degrading.

\section{REFERENCES}

Ashori, A. 2008. Wood-plastic composites as promising green-composites for automotive industries. Bioresources Technology (99): 4661-4667.

Ashori, A. 2006. Non-wood fibers - a potential source of raw material in papermaking. PolymerPlastics Technology Engineering 45(10): 1133- 1136.

American Society for Testing and Materials. ASTM. 2004. Standard Test Method for Tensile Properties of Plastics. ASTM D 638. West Conshohocken, PA. 08 (01).

American Society for Testing and Materials. ASTM. 2004. Flexural Properties of Unreinforced and Reinforced Plastics and Electrical Insulating Materials. ASTM D 790. West Conshohocken, PA. 08 (01).

American Society for Testing and Materials. ASTM. 2010. Standard specification for polyolefinbased plastic lumber decking boards. ASTM D6662-09. West Conshohocken, PA. 08 (03).

Basiji, F.; Safdari, V.; Nourbakhsh, A.; Pilla, S. 2010. The Effects of Fiber and Fiber Loading on the Mechanical Properties of Wood-Plastic (Polypropylene) Composites. Turkish Journal of Agriculture and Forestry 34: 191-196.

Canetti, M.; Bertini, F.; Chrico, A.D.; Audisio, G. 2006. Thermal degradation behavior of isotactic polypropylene blended with lignin. Polymer Degradation and Stability 91: 494-498.

Clemons, C. 2002. Wood-Plastic Composites in the United States. The interfacing of two industries. Forest Products Journal 52(6): 10-18.

European Committee for Standardization. EN. 1996. Test method for determining the protective efectiveness against wood destroying basidiomycetes. Determination of the toxic values. EN113. Brussels.

Gallagher, L.W.; McDonald, A.G. 2013. The effect of micron sized wood fibers in wood plastic composites. Maderas. Ciencia y tecnologia 15(3): 357-374.

H'ng, PS.; Lee, A.N.; Hang, C.M.; Lee, S.H.; Khalina, A.; Pridah, M.T. 2011. Biological durability of injection moulded wood plastic composite boards. Journal of Applied Sciences 11(2): 284-288. 
Ismail, H.; Nizam, J.M.; Abdul Khalil, H.P.S. 2001. The effect of a compatibilizer on the mechanical properties and mass swell of white rice husk ash filled natural rubber/linear low density polyethylene blends. Polymer Testing 20(2): 125-33.

Kartal, N.K.; Aysal, S.; Terzi, E.; Yılgör, N.; Yoshimura, T.; Tsunoda, K. 2013. Wood and bambooPP composites: Fungal and termite resistance and water absorption. Bioresources 8(1): 1222-1244.

Khavkine, M.; Kazayawoko, M.; Law, S.; Balatinecz, J.J. 2001. Durability of wood flourthermoplastic composites under extreme environmental conditions and fungal exposure. International Journal of Polymeric Material 46: 255-269.

Klyosov, A.A. 2007. Wood plastic composites. New Jersey, USA, Wiley-Intersence .

Kord, B. 2012. Effects of compatibilizer and nanolayered silicate on physical and mechanical properties of PP/bagasse composites. Turkish Journal of Agriculture and Forestry 36: 510-517.

Kooperatğfçğlġk Genel Müdürlüğü. 2013. Turkish Ministry of Customs and Trade Report 2013. pp.4-6. <http://koop.gtb.gov.tr/data/51f7a45f487c8e14b4454603/2012\%20Y\%C4\%B11\%C4\%B1\%20 F\%C4\%B1nd\%C4\%B1k\%20Raporu.pdf>.

Li, Q.; Matuana, L.M. 2003. Effectiveness of maleated and acryclic acid-functionalized polyolefin coupling agents for HDPE-woodflour composites. Journal of Thermoplastic Composite Materials 16 : 551-564.

Matuana, L.M.; Park, C.P.; Balatinecz, J.J. 1998. Cell morphology and property relationships of microcellular foamed PVC/Wood-fiber composites. Polymer Engineering and Science 38: 1862-1872.

Mengeloglu, F.; Matuana, L.M.; King, J.A. 2000. Effects of Impact Modifiers on the Properties of Rigid PVC/Wood-Fiber Composites. Journal of Vinyl and Additive Technology 6(3): 153-157.

Mengeloglu, F.; Matuana, L.M. 2003. Mechanical Properties of Extrusion foamed Rigid PVC/ Wood-Flour Composites. Journal of Vinyl and Additive Technology 9(1): 26-31.

Mengeloglu, F.; Karakus, K. 2008. Polymer-Composites from Recyled High Density Polyethylene and Waste Lignocellulosic Materials. Fresenius Environmental Bulletin 17(2): 211-217.

Mengeloglu, F.; Kurt, R.; Gardner, D.J.; O’Neill, S. 2007. Mechanical Properties of Extruded High Density Polyethylene and Polypropylene Wood Flour Decking Boards. Iranian Polymer Journal 16(7): 477-487.

Moreno, P.; Rodrigue, D.; Giroux, Y.; Ballerini, A.; Gacitua, W. 2013. Morphological and mechanical caracterization of recyceled thermoplastic foams reinforced with wood sub-products. Maderas. Ciencia y tecnologia 15(1): 3-16.

Sain, M.; Panthapulakkal, S. 2006. Bioprocess preparation of wheat straw fibers and their characterization. Industrial Corps and Products (23): 1-8.

Sanadi, A.R.; Caulfield, D.F.; Rowell, R.M. 1994. Reinforcing polypropylene with natural fibers. Plastics Engineering (4): 27-30.

Schirp, A.; Wolcott, M.P. 2005. Infuluence of fungal decay and moisture adsorption on mechanical properties of extruded wood-plastic composite. Wood and Fiber Science (37): 643-652. 
Taşçıŏlu, C.; Tufan, M.; Yalcın, M.; Şen, S. 2014. Determination of Biological Performance, Dimensional Stability, Mechanical and Thermal Properties of Wood Plastic Composites Produced From Recycled Chromated Copper Arsenate Treated Wood. Journal of Thermoplastic Composite Materials, 1-19. DOI: $10.1177 / 0892705714565704$.

Taş̧̧ığlu, C.; Yoshimura, T.; Tsunoda, K. 2013. Biological performence of wood plastic composites containing zinc borate: Laboratory and 3-year field test results. Composites: Part B (51): 185-190.

Verhey, S.; Laks, P.; Richert, D. 2001. Laboratory decay resistance of woodfiber/thermoplastic composites. Forest Products Journal 51(9): 44-49.

Wang, Y.C.; Wong, P.M.H.; Kodur, V. 2007. An experimental study of the mechanical properties of fibre reinforced polymer (FRP) and steel reinforcing bars at elevated temperatures. Composite Structures (80): 131-140.

Wang, Q.; Zhu, S. 2010. Genetically modified lignocellulosic biomass for improvement of ethanol production. Bioresources 5(1): 3-4.

Wang, Z.; Wang, E.; Zhang, S.; Wang, Z.; Ren, Y. 2009. Effects of cross-linking on mechanical and physical properties of agricultural residues/recycled thermoplastics composites. Industrial Crops and Products 29(1): 133-138.

Xu, F.; Liu, C.F.; Geng, Z.C.; Sun, J.X.; Sun, R.C.; Hei, B.H.; Lin, L.; Wu, S.B.; Je, J. 2006. Characterization of degraded organosolv hemicelluloses from wheat straw. Polymer Degradation and Stability (91): 1880-1886.

Yang, H.S.; Wolcott, M.P.; Kim, H.S.; Kim, S.; Kim, H.J. 2007. Effect of different compatibilizing agents on the mechanical properties of lignocellulosic material filled polyethylene bio-composites. Composite Structures (79): 369-375.

Youngquist, J.A. 1995. Unlikely partners the marriage of wood and non-wood materials. Forest Products Journal 45(10): 25-30. 